\title{
Mini crusher-shredder for farms
}

\author{
Komil Astanakulov ${ }^{1}$, Fakhriddin Karshiev $^{2 *}$, Shokir Gapparov ${ }^{1}$, Dilshod Khudaynazarov ${ }^{3}$ \\ and Shavkat Azizov ${ }^{2}$ \\ ${ }^{1}$ Tashkent Institute of Irrigation and Agricultural Mechanization Engineers, Tashkent, Uzbekistan \\ ${ }^{2}$ Karshi Institute of Engineering and Economics, Karshi, Uzbekistan \\ ${ }^{3}$ Tashkent State Technical University, Tashkent, Uzbekistan
}

\begin{abstract}
The purpose of the study is to substantiate the parameters of a mini crusher-shredder for processing coarse feed stalks in farms. The feasibility of using a mini crusher-shredder for processing coarse feed in the conditions of farms and farms with a small number of animals, which has a rotary-type shredder that combines the operations of grinding and crushing, is justified. The research uses the laws and rules of mathematical statistics, mathematical planning of experiments, and the methods given in existing regulatory documents. Experimental studies were carried out to study the influence of the rotor parameters of the mini crusher-shredder on its quality performance. A compact crusher-shredder has been developed, which has good visibility of the working bodies, high reliability, and quality of work due to zootechnical requirements. Experimental studies have established that when using a hammer of a flat-turned shape with a lower sharpening and a rotation angle of 60 or more, high-quality grinding of the stems is provided.
\end{abstract}

\section{Introduction}

Animal husbandry in Uzbekistan is one of the most important branches of agriculture. In this regard, special attention is paid to providing the livestock industry with feed, while special importance is attached to the cultivation of forage crops [1-26]. Therefore, Uzbekistan is conducting research on the development of energy and resource-saving technologies and technical means for tillage [19, 25], seeding and harvesting [3, 10, 11, 19, 20], forage crops, and their primary processing [1, 14, 22].

Much attention is paid to the development of animal husbandry in private subsidiary farms, farms, and farms with a small number of animals. Numerous farms with a small number of cattle (cattle) and sheep are organized in the Republic. To date, the number of cattle in the Republic has increased dramatically and is more than 7.4 million. Of these, 6.9 million or more than $90 \%$ comes to the share of personal subsidiaries and farms.

In our Republic, coarse feed is mainly used for feeding animals, i.e., corn stalks, alfalfa hay, straw, and wild-growing stalked crops [27-28]. However, due to poor cooking food using primitive (cutting the stems) and ineffective (grinding with obsolete equipment) ways

* Corresponding author: fkarshiev@mail.ru 
of increasing feed waste due to its low consumption and operating costs [27-28].

One of the necessary and required conditions for the successful management of industrial livestock is a stable feed base and the use of modern methods and techniques for preparing feed, ensuring their most effective use.

The most important source of feed proteins for animal husbandry is coarse feed. However, to improve the quality and digestibility of coarse feed, it is necessary to process them.

It is known that the development of small livestock farms and farmer farms is closely associated with the preparation of quality food at a lower material cost [27-28].

The solution to the problematic issue of livestock eliminates the above drawbacks predetermines the necessity of the work aimed at developing the mini crusher, shredder, providing improvement of quality of feed preparation of coarse stems of forage crops, as well as reducing operating costs.

The purpose of the study is to substantiate the parameters of a mini crusher-shredder for processing coarse feed stalks in farms.

\section{Methods}

In accordance with the task of creating a rational design of the crusher-shredder and to justify the main parameters and operating modes of the crusher-shredder, complex experimental studies were conducted [28].

Studies of the process of processing coarse feed were carried out in the laboratory and field conditions. The main provisions of OST-70.19.2-83 "Testing of agricultural machinery" were used as a methodology for conducting research. Machinery and equipment for the preparation of feed. Research programs and methods" [29]. The repetition of experiments with each variant was taken five times.

The stalks of corn, which is the main coarse feed, were selected for the research. Stem samples taken to determine the quality were weighed on a VLKT-500A scale. Before starting the experiments, the humidity of the stems and their size and weight indicators were determined. The evaluation criteria for the quality of the machine were: the quality of grinding $\left(C_{i}\right)$, the cleavage of the stems $\left(R_{s}\right)$. The choice of the shape of the rotor hammers was evaluated based on the condition of better embed ability in the crushed mass and the implementation of the technological process with fewer technological failures of the machines.

Experimental studies on the interaction of coarse feed stalks depending on the parameters and operating modes of the rotor were carried out on a specially made stand. A three-phase asynchronous motor drives the working bodies of the stand via a V-belt transmission. An electric motor drives the working rotor through a pulley, which changes the speed of rotation. The rotor speed can be adjusted by replacing the pulleys within 900$1500 \mathrm{~min}^{-1}$. The design of the stand provides for the possibility of easy replacement of working bodies. 


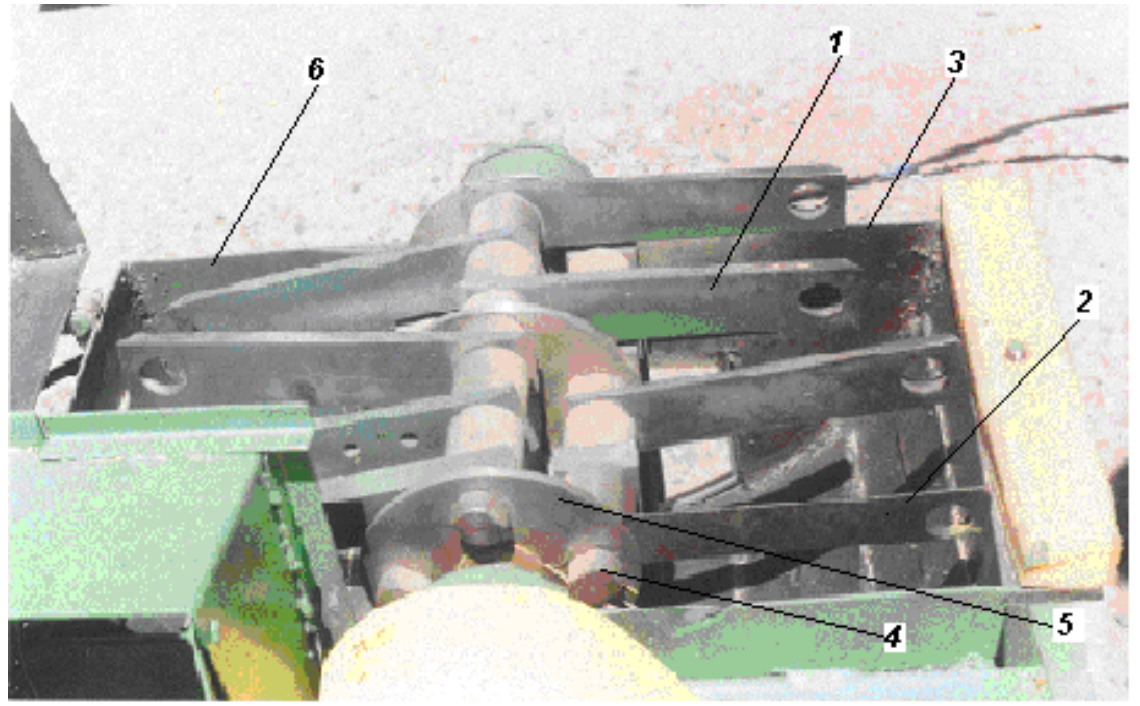

Fig. 1. General view of the rotor: 1 is hammer; 2 is knife; 3 and 6 is rotor body; 4 are axis; 5 is flange

The rotor consists of a shaft on which three disks of steel sheet with a thickness of $8 \mathrm{~mm}$ are mounted. The disks on the periphery have holes that serve to secure the hammers with a threaded connection. Fixing the hammers with bolted connections allowed changing the diameter of the rotor from 0.4 to $0.6 \mathrm{~m}$ and the number of hammers from 12 to 24 pieces of various options.

\section{Results and Discussion}

Selection of the shape and angle of rotation of the rotor hammers. The selection of the optimal type and shape of the rotor hammers of the crusher-shredder was carried out by comparative tests. The choice of the working shape of the rotor hammers was evaluated based on the conditions of better embed ability in the supplied mass of stems and the implementation of the technological process, with a few technological failures as possible.

For a comparative study, the following forms of rotor hammers were selected: straight, straight with a sharpened lower part, turned, each of which was straight.

A comparative evaluation of the operation of different versions of the rotor hammers was carried out under the same conditions and operating modes. The results of the experiments are presented in Table 1.

Table 1. Performance indicators of the crusher-shredder with different shapes of hammers

\begin{tabular}{|c|c|c|c|}
\hline \multirow{2}{*}{ Name of indicators } & \multicolumn{3}{|c|}{ Values of indicators } \\
\cline { 2 - 4 } & flat straight & $\begin{array}{c}\text { straight to the } \\
\text { lower shank }\end{array}$ & flat turned \\
\cline { 2 - 4 } & & 4.0 & 2.8 \\
1. Time of drawing of the supplied mass, c & 4.2 & 3.8 & 1.7 \\
2. Time of passage of the mass, c & 5.6 & 18.7 & 0.6 \\
3. Reverse blowing of the mass, \% & 31.4 & 98.1 & 93.2 \\
4. Grinding, \% & 92.8 & 89.3 & 84.9 \\
5. Cleavage, \% & 94.5 & \multicolumn{2}{|c|}{$\%$} \\
\hline
\end{tabular}

From these experiments, it can be seen that the worst indicators for the time of dragging the supplied mass $(4.2 \mathrm{~s})$, the passage of the mass $(5.6 \mathrm{~s})$, and the reverse blowing of the 
mass $(31.4 \%)$ were obtained when the crusher-shredder with a flat cross-section shape of the rotor hammers.

This phenomenon is explained by the low degree of embed ability of the hammers in the feed mass and the poor transportability of the crushed mass by this type of hammers since they create an air flow not in the direction of the mass exit but in the direction of the feed tray.

Slightly better performance is obtained when the rotor works with a straight hammer with a lower sharpening. So, with the same feed and operating mode, the time of dragging and passing the mass is 4.0 and 3.8 seconds, respectively, and the reverse blowing of the mass is $18.7 \%$.

This is because the lower sharpening of the hammers contributes to creating an air flow towards the discharge window, and a larger number of processed stems come out of the discharge window.

The best indicators for these three evaluation criteria were obtained with flat-turned hammers with a lower sharpening, while the dragging time is $2.8 \mathrm{~s}$, and the mass passage time through the device is $1.7 \mathrm{~s}$. The reverse blowing of the mass almost did not occur.

The improvement of dragging, passing, and blowing of the mass with the rotor hammers turned is explained by the fact that the hammers having this shape better capture the supplied mass and create an excellent air flow towards the mass exit, as well as sufficiently throw the processed mass into the discharge window of the crusher-shredder.

In addition, these variants of hammers were compared by the shredding and splitting of the stems.

Of the compared variants of the working bodies on the criteria of atomization and the split, the best results are hammers with the cross-sectional shape of a flat straight and direct with bottom sharpening, these values are respectively 92,8 and atomization of $98.1 \%$, and the split - 94,5 and $89.3 \%$. When operating the rotor with flat-turned hammers, these indicators were 93.2 and $84.9 \%$.

Analyzing the data obtained, it can be noted that although the first and second types of hammers have a higher value of shredding and splitting of the stems than the third option, they are not significant.

However, the third version of the hammers performs the technological process better and processes the stems much faster. Therefore, this type of working body was chosen by us for further research to determine the optimal parameters and operating modes of the crusher-shredder.

The rotor hammers grind and split the stems and move the processed mass to the exit part of the discharge window. Therefore, the angle of rotation of the hammers significantly affects the efficiency of the process of moving and transporting the crushed mass. At the same time, it is necessary to find such an angle of rotation of the hammers that the quality of work on transporting the crushed mass is satisfactory. Otherwise, the crushed mass at small angles of rotation is blown out through the feed window and complicates the work of the feeder, and at large angles-the mass is pinched inside the working chamber, which leads to its faces.

The results of comparative tests of straight, straight with bottom sharpening and flatturned forms of rotor hammers showed that flat-turned hammers provide the best performance with bottom sharpening. The obtained data (Fig.1) show that with an increase in the angle of rotation of flat-turned hammers with a lower sharpening from 30 to 90 , the quality of grinding and splitting of stems increases, respectively, from $78.6 \%$ to $84.6 \%$ and from $86.4 \%$ to $87.5 \%$. Increasing the angle of rotation of the hammers to 120 led to a decrease in these indicators, and they are 82.3 and $85.5 \%$, respectively. 


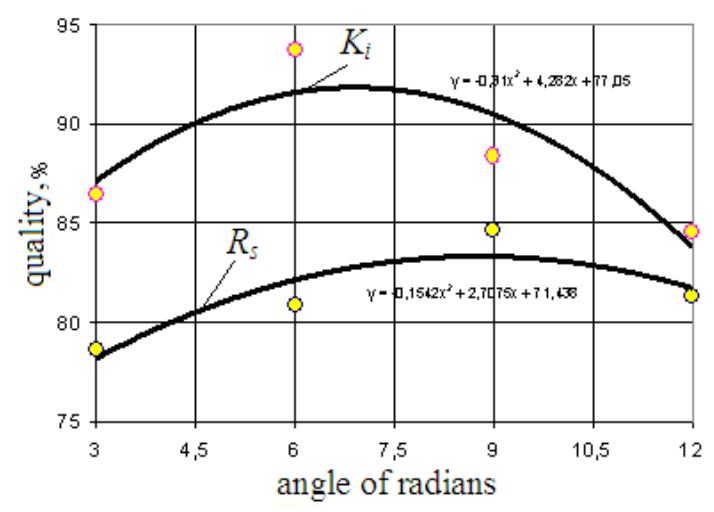

Fig. 1. Influence of the angle of rotation of the hammer on the quality of grinding and cleavage

This is because with an increase in the angle of rotation of the hammers from 30 to 90 , the impact on the processed mass improves. However, a further increase in the angle of rotation of the hammer leads to a rapid movement of the processed mass, and the working bodies do not have time to grind fully and split it in the working chamber.

Based on the obtained research results, we, jointly with JSC "BMKB-Agromash," developed and manufactured a mini crusher-shredder with optimal parameters of the working bodies (Fig.2).

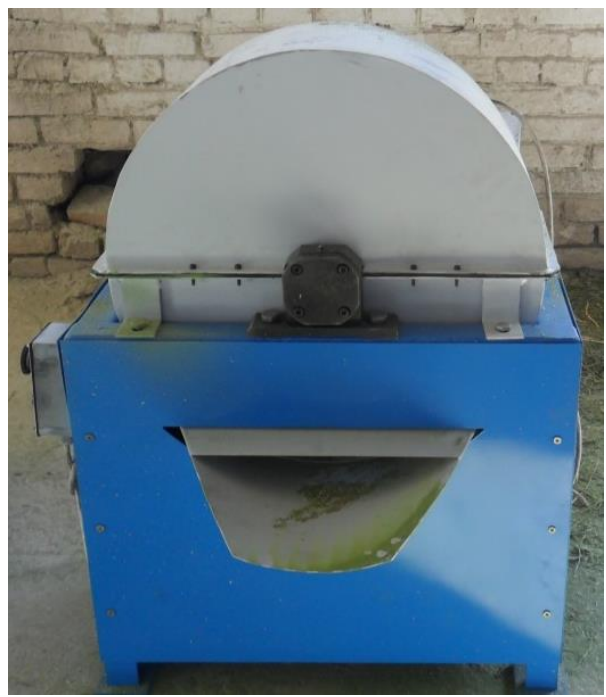

Fig. 2. Mini crusher-shredder for farms

\section{Conclusions}

1. In the conditions of farms and dehkan farms with a small number of animals for processing coarse feed, it is advisable to use a mini crusher-shredder, which has a rotary-type shredder that combines the operations of grinding and crushing.

2. A compact crusher-shredder has been developed, which has good visibility of the working bodies, high reliability, and quality of work due to zootechnical requirements.

3. According to the results of experimental studies, it was found that when using a hammer of a flat-turned shape with a lower sharpening and a rotation angle of 60 , high-quality 
grinding of the stems is provided.

\section{References}

1. Mamatov, F.M., Eshdavlatov, E., Suyunov, A. The Shape of the Mixing Chamber of the Continuous Mixer // Jour of Adv Research in Dynamical \& Control Systems, Vol. 12, 07-Special Issue, (2020). DOI: 10.5373/JARDCS/V12SP7/20202318 ISSN 1943$023 \mathrm{X}$.

2. Mamatov, F., Ergashev, I., Ochilov, S., Pardaev, X. Traction Resistance of Soil Submersibility Type "Paraplau" // Jour of Adv Research in Dynamical \& Control Systems, Vol.12, 07-Special Issue, (2020). DOI: 10.5373/JARDCS/V12SP7/20202336 ISSN1943-023X.

3. Aldoshin, N., Mamatov, F., Ismailov, I., Ergashov, G. Development of combined tillage tool for melon cultivation // 19th international scientific conference engineering for rural development Proceedings, Jelgava,(2020). Volume 19. ISSN 1691-5976. DOI:10.22616/ERDev.2020.19.TF175.

4. Umurzakov, U., Mirzaev, B., Mamatov, F., Ravshanov, H., Kurbonov, S. A rationale of broach-plow's parameters of the ridge-stepped ploughing of slopes // XII International Scientific Conference on Agricultural Machinery Industry IOP Conf. Series: Earth and Environmental Science 403(2019) 012163 IOP Publishing doi:10.1088/1755-1315/403/1/012163.

5. Mirzaev, B., Mamatov, F., Chuyanov, D., Ravshanov, X., Shodmonov, G., Tavashov, $\mathrm{R}$ and Fayzullayev, $\mathrm{X}$. Combined machine for preparing soil for cropping of melons and gourds // XII International Scientific Conference on Agricultural Machinery Industry. doi.org/10.1088/1755-1315/403/1/012158.

6. Mirzaev, B., Mamatov, F., Ergashev, I., Ravshanov, H., Mirzaxodjaev, Sh., Kurbanov, Sh., Kodirov, U and Ergashev, G. Effect of fragmentation and pacing at spot ploughing on dry soils // E3S Web of Conferences 97. doi.org/10.1051/e3sconf/201913501065.

7. Mamatov, F., Mirzaev, B., Shoumarova, M., Berdimuratov, P., Khodzhaev, D. Comb former parameters for a cotton seeder// International Journal of Engineering and Advanced Technology (IJEAT) Volume-9 Issue1 October/ DOI: 10.35940/ijeat.A2932.109119.

8. Mamatov, F., Mirzaev, B., Batirov, Z., Toshtemirov, S., Tursunov, O., Bobojonov, L. Justification of machine parameters for ridge forming with simultaneous application of fertilizers // CONMECHYDRO - 2020 IOP Conf. Series: Materials Science and Engineering 883(2020) 012165 IOP Publishing. doi:10.1088/1757$899 X / 883 / 1 / 012165$.

9. Mirzaev, B., Mamatov, F., Avazov, I., Mardonov, S. Technologies and technical means for anti-erosion differentiated soil treatment system// E3S Web of Conferences. doi.org/10.1051/e3sconf/20199705036.

10. Aldoshin, N., Didmanidze, O., Mirzayev, B., Mamatov, F. Harvesting of mixed crops by axial rotary combines // Proceeding of $7^{\text {th }}$ International Conference on Trends in Agricultural Engineering 2019. $17^{\text {th }}-20^{\text {th }}$ Prague, Czech Republic. - pp.20-26. September (2019).

11. Mirzaev, B., Mamatov, F., Aldoshin, $\mathrm{N}$ and Amonov, M. Anti-erosion two-stage tillage by ripper// Proceeding of 7th International Conference on Trends in Agricultural Engineering 17th-20th. Prague, Czech Republic. - pp.391-396. September (2019).

12. Mirzaev, B., Mamatov, F., Ergashev, I., Islomov, Yo., Toshtemirov, B., Tursunov O. Restoring degraded rangelands in Uzbekistan // Procedia Environmental Science, № 6. - pp 395-404. (2019). 
13. Uzakov, Z.U., Mamatov, F.M., Begulov, O. Implementation of object-oriented Programming technology in the one-dimensional oil displacement problem // International Conference on information Science and Communications Technologies: ICISCT 2019/0012008. Tashkent, Uzbekistan. INSPEC Accession Number: 19412491. DOI: 10.1109/ICISCT47635.2019.9012008.

14. Mamatov, F., Mirzaev, B., Berdimuratov, P., Turkmenov, Kh., Muratov, L., Eshchanova, G. The stability stroke of cotton seeder moulder // CONMECHYDRO 2020. IOP Conf. Series: Materials Science and Engineering 883 (2020) 012145 IOP Publishing. doi:10.1088/1757-899X/883/1/012145.

15. Mamatov, F., Mirzaev, B., Tursunov, O. A Justification of Broach-Plow's Parameters of the Ridge-Stepped Ploughing // E3S Web of Conferences 97, 05035 (2019). doi.org/10.1051/e3sconf/20199705035.

16. Ahmedov, B.J., Mirzaev, B.S.,Mamatov, F.M., Khodzhaev, D.A., Julliev, M.K. Integrating of gis and gps for ionospheric perturbations in d- And f-layers using vlf receiver // InterCarto, InterGIS 26, - c. 547-560. DOI: 10.35595/2414-9179-2020-1-26547-560.

17. Mamatov, F., Mirzaev, B., Tursunov, O., Ochilov, S and Chorieva, D. Relief, physicomechanical and technological properties of soil in the cotton growing area // ICECAE 2020. IOP Conf. Series: Earth and Environmental Science 614(2020) 012169. IOP Publishing. doi:10.1088/1755-1315/614/1/012169.

18. Shamsutdinov, Z., Ubaydullaev, Sh., Shamsutdinov, N., Mirzaev, B., Mamatov, F., and Chorshabiyev, N. The concept of the phytogenic field: theory, research experience and practical significance // ICECAE 2020. IOP Conf. Series: Earth and Environmental Science 614(2020) 012164. IOP Publishing. doi:10.1088/1755-1315/614/1/012164.

19. Umurzakov, U., Mamatov, F., Aldoshin, N., and Mirzaev, B. Exploration of tillage technologies in the Republic of Uzbekistan // ICECAE 2020 IOP Conf. Series: Earth and Environmental Science 614(2020) 012168. IOP Publishing. doi:10.1088/17551315/614/1/012168.

20. Mamatov, F., Aldoshin, N., Mirzaev, B., Ravshanov, H., Kurbanov, Sh and Rashidov, N. Development of a frontal plow for smooth, furless plowing with cutoffs // IPICSE 2020. IOP Conf. Series: Materials Science and Engineering 1030 (2021) 012135 IOP Publishing. doi:10.1088/1757-899X/1030/1/012135.

21. Mamatov, F., Mirzaev, B., Mirzahodzhaev, Sh., Uzakov, Z and Choriyeva, D. Development of a front plow with active and passive working bodies // IPICSE 2020. IOP Conf. Series: Materials Science and Engineering 1030 (2021) 012164. IOP Publishing. doi:10.1088/1757-899X/1030/1/012164.

22. Mamato, F.M., Eshdavlatov, E., Suyuno, A. Continuous Feed Mixer Performance //Journal of Advanced Research in Dynamical and Control Systems (JARDCS). Volume-12, 07-Spesia1 Issue, 2020. DOI: 10.5373/JARDCS/V12SP7/20202343. ISSN 1943-023X.

23. Mamatov, F., Ergashev, I., Mirzaev, B., Pardaev, X, Chorieva, D. Research of the Penetration Process of the Frontal Plow // 2nd Bukittinggi International Conference on Education (BICED) 2020. Journal of Physics: Conference Series 1779 (2021) 012002. IOP Publishing. doi:10.1088/1742-6596/1779/1/012002.

24. Mamatov F.M., Mirzaev B.S., Avazov I.Zh.. Agrotehnicheskie osnovy sozdanija protivojerozionnyh vlagosberegajushhih tehnicheskih sredstv obrabotki pochvy $\mathrm{v}$ uslovijah Uzbekistana // - Prirodoobustrojstvo, (2014).

25. Mamatov F.M., Mirzaev B.S. Erosion preventive technology of crested ladder-shaped tillage and plow design // European Applied Sciences.- pp. 71-73. Stuttgart (Germany), (2014).

26. Lobachevskij Ja.P., Mamatov F., Jergashev I.T. Frontal'nyj plug dlja hlopkovodstva // 
- Hlopok, № 6.pp-35-37 (1991).

27. OST-70.19.2-83 «Ispytanija sel'skohozjajstvennoj tehniki. Mashiny i oborudovanie dlja prigotovlenija kormov. Programmy i metody issledovanij». p. - 167. (1983).

28. Reznik E.I., Ryzhov S.V. Ocenka kachestva izmel'chenija grubyh kormov. // Tehnika v sel'skom hozjajstve. №4, (1986).

29. Drobilka-izmelchitel' universal'naja grubyh kormov i guzapai v tjukah i rulonah DIU-7. Tehnicheskoe opisanie i instrukcija po jekspluatacii. p. -26. Jangijul'-Bishkek. (1993).

30. Karshiev F.U., Kulametov N.A. Izuchenie rasshheplenija steblej v rabochej kamere izmel'chitel'ja-drobilki // Sbornik dokladov respublikanskih nauchno-tehnicheskih konferencij s uchastiem zarubezhnyh uchenyh. -Tashkent, (2004).

31. Karshiev F.U. Obosnavenie parametrov rabochih organov mini drobilki-izmel'chitelja grubyh kormov. Avtoreferat diss... kand. tehn. nauk. p. -22. -Tashkent, (2007).

32. Golikov V.A., Abilzhanov T., Kujkenov A.Z. Drobilka izmel'chitel' kormov mnogocelevogo naznachenija. // Tehnika v sel'skom hozjajstve. № 4.- pp. 15-16. (1987).

33. Delendik K., Golushko P. Universal'nyj izmel'chitel'. // Sel'skij mehanizator. №8, p 23. [In Russian].

34. Karshiev F.U. Patent RUz № IAP 03193. Molotkovaja drobilka. (1986).

35. Astanakulov K., Gapparov Sh., Karshiev F., Makhsumkhonova A and Khudaynazarov D. Study on preparation and distribution of forage by chopping coarse fodder // ICECAE 2020. IOP Conf. Series: Earth and Environmental Science 614(2020) 012158. IOP Publishing. doi:10.1088/1755-1315/614/1/012158

36. Gapparov Sh, Karshiev F. Development chopper device that chops baled rough fodders // CONMECHYDRO - 2020. IOP Conf. Series: Materials Science and Engineering 883(2020) 012158. IOP Publishing. doi:10.1088/1757-899X/883/1/012158. 